\title{
Comparison of emissions depending on the type of vehic le engine
}

\author{
Vla dimír RIEVAJ ${ }^{1}$, Ján GAŇA ${ }^{1}$ a nd František SYNÁK*1 \\ 1 University of Zlina, Fa culty of Operation and Ec onomic s of Transp ort and \\ Communic ations/Department of Road and Urban Transport, Zlina, Slova kia
}

\begin{abstract}
Road transport is showing growth in the period of globalization. Its task is to transport cargo as well as people to the required location within the shortest possible time and at the lowest price. Thus, road transport plays a crucial role in enabling the globalization to be developed and improved. However, the intemal combustion engine hat prevail among the vehicles of freight and passenger transport are the producers of gaseous emissions from the exhaust gases. Many developed countries of the world has committed themselves, inter alia also trough the Paris Agreement, to reduce global waming, and thus to reduce the production of hamful gaseous emissions. The result is the endeavour to replace the intemal combustion engine vehicles that bum carbon fuels with the vehicles powered by electric motors consuming electric energy. The reason of such trying claims that road transport using the intemal combustion engine vehicles is environmentally aggressive, and the problem would not be solved by implementation of the vehicles with electric motors. Such claim is based on the fact that an electric car does not produce any of primary emissions. From an overall perspective, it is also necessary to take into account secondary emissions that are produced duning the electric energy production by which is the vehicle with electric motor powered. The pumose of this article is to assume the possibility of reducing global pollution by replacing the intemal combustion engine vehicles with the vehicles powered by electric motors in dependence with producing the emissions during the production of electric energy.
\end{abstract}

Index Terms-electric energy, emissions, electric vehicle, intemal combustion engine, global pollution

\section{INTRODUCTION}

It is a well-known fact that the Earth is wa ming up and the average temperatures are rising [1]. This causes melting of the ice on both poles of the Earth. It is caused by the greenhouse effect which is the result of $\mathrm{CO}_{2}$ emitits [2]. This gas is considered the main gas causing the greenhouse effect, although not the only one [3]. Other gases also contribute to the greenhouse effect and their impact on the total waming is calculated by coefficient [4]. If we want to slow down global warming and thus slow down melting of the ice and rising of sea levels, the only way is to reduce emits of the greenhouse gases [5]. Melting of ice and associated rising of sea levels is a big threat for maritime countries which could loose vast areas [6]. Therefore, the only solution is to reduce the emits of greenhouse gases. Transport is considered one of the main producers of these gases, specific ally, intemal combustion engines which use the energy of hydrocarbon fuels [7]. One of the often claimed solutions is that by the use of electric energy this problem would be eliminated [8]. Another frequently used statement is that the road transport is not ecological [9].

Emissions of road vehic les

Road vehicles get the energy necessary to overcome road resistance by combustion of hydrocarbon fuels [9]. Buming at high pressure and temperature generates many gaseous emissions which are contained in the exhaust gases [9]:

nitrogen - $\mathrm{N}_{2}$,

oxygen $-\mathrm{O}_{2}$,

water, watervapour $-\mathrm{H}_{2} \mathrm{O}$,

carbon monoxide - $\mathrm{CO}$,

carbon dioxide $-\mathrm{CO}_{2}$,

sulphur dioxide $-\mathrm{SO}_{2}$,

hydroc arbons- HC,

nitrogen oxides- $\mathrm{NO}_{x}$,

partic ulate matter [8]. 


\section{Carbon dioxide $\mathrm{CO}_{2}$}

It is regarded as the most spread greenhouse gas with the share of about $55 \%$. Carbon dioxide is colourless, non-toxic gas, heavier than a ir. Thanks to photosynthesis in plants it cyclically retums back to biosphere. Combustion of fossil fuels relea ses into a ir a bout $1,4.10^{10} \mathrm{t} \mathrm{CO}_{2}$ every year. At present, the a mount of carbon dioxide inc rea ses annually by $0.2 \%$ [15].

Sulphur dioxide $\mathrm{SO}_{2}$

is colourless, non-flammable gas with pungent odour. It causes respiratory diseases. In exhaust gases it is conta ined only in small amount if sulphur conta ining fuel was used [16].

Hydrocarbons $\mathrm{HC}$

are the result of a poorly bumed fuel. They exist in many various forms as unbumed or partially bumed fuel components. Some hydrocarbons imitate sense organs, others are carcinogenic (benzole) [17].

Nitrogen oxides $\mathrm{NO} x$

Combustion of hydrocarbon fuels at high temperature and pressure and sufficient amount of oxygen results in the occurrence of nitrogen oxide $\mathrm{NO}$ and nitrogen dioxide $\mathrm{NO}_{2}$. Their percentage in exhaust gases is $10-20 \%$ in $\mathrm{Cl}$ engines, compression ignitigion, and $2 \%$ in Sl engines, spark ignitions engines. They react with haemoglobin and modify the iron in haemoglobin from $\mathrm{Fe}^{2+}$ to $\mathrm{Fe}^{3+}$ and thus create a haemoglobin modification - methaemoglobin, which is stable and unable to bind oxygen. In large concentrations they react with moisture in lungs and create nitric acid and nitrous acid which cause acute respiratory disease [18]. Nitrogen oxidesaggravate:

- heart diseases,

- cyanosis (blue-purplish discolouration of skin and mucous membrane by insufficient oxygenation of blood caused by the increase of the amount of reduced haemoglobin to over $50 \mathrm{~g} / \mathrm{l})$,

- they have vasodilating effect which causes lowering of blood pressure,

- they cause pneumonia and swelling of lungs,

- leaves of plants tum pale, get sma ller and, finally, wither,

- nitrogen oxidescatalyse oxidation of $\mathrm{SO}_{2}$ to more ha mful $\mathrm{SO}_{3}$.

Nitrous oxide, $\mathrm{N}_{2} \mathrm{O}$, is a colourless gas with plea sant odour and sweetish taste. It disnupts the ozone layer and causes greenhouse effect 310-times more effectively than $\mathrm{CO}_{2}$. The life of nitrous oxide in the atmosphere is estimated at $\mathbf{1 5 0}$ years. It is toxic for humans and when inhaled it has caustic effect on mucous membranes. In small amounts it causes intoxication and in higher doses it acts as a narcotic. It causes deterioration of psychomotor performance, worsens the ability to leam and remember [8].

Nitrogen oxide, NO, is created at temperature higher than $1300{ }^{\circ} \mathrm{C}$ (at the end of expansion the temperature inside cylinders reaches up to $1000-1800^{\circ} \mathrm{C}$ ). In contact with oxygen it reacts to nitrogen dioxide and in combination with water it creates nitric acid. It reacts with metals and organic substances. It creates weak acids in rainfall water and contributes to the creation of photoc hemic al smog. In orga nism it has an important biologic al function. It sec ures communic ation between the cells [9].

Nitrogen dioxide, $\mathrm{NO}_{2}$, is created by oxidation of nitrogen oxide in flame as well as in the free air.

It is more toxic and more active than nitrous oxide and nitrogen dioxide. It is a malodorous gas and when inhaled it causes imitation. When inhaled by asthmatic it causes an asthmatic attack. Ultraviolet radiation causes a chemical reaction resulting in the occurrence of ground-level ozone [19].

\section{Partic ulate matter PM}

The EU set the limit for their oc currence at $50 \mathrm{mg} / \mathrm{m}^{3}$ as a 24-hour average for the concentration of microparticles smaller than $10 \mu \mathrm{m}-\mathrm{PM} 10 .\left(1 \mu \mathrm{m}=10^{-6} \mathrm{~m}\right)$. Partic les with the size of 10 and more $\mu \mathrm{m}$ collect in the nose and mucous membranes. Particles smaller than $2 \mu \mathrm{m}$ penetrate deep into the lungsand can damage the lung cells [20].

The emissions of particulate matter in the EU cause 25 million respiratory disea ses and 32 thousand premature deaths annualy [8]. Increase in the concentration of particulate matter in the a ir by 10 $\mathrm{mg} / \mathrm{m}^{3}$ leads to $1 \%$ mortality growth. Increase of the particle concentration by every 30 $\mathrm{mg} / \mathrm{m}^{3}$ results in the increase of asthmatic attacks by $12 \%$. The risk of lung cancer is higher for the people living in cities than for people living in cleanerareas [8]. 
Every one of these gases is rea lly hamful or dangerous. That is why their a mount in vehic le exhaust gases is limited and these limits a re regularly tightened [21]. Development of the permissible values is shown in Table 1 and 2. The amount of allowed emissions differs based on the type of combustion cycle for Sl engines and $\mathrm{Cl}$ engines of the category $\mathrm{M} 1$ vehicles and for other motor vehic les.

Table 1 Emission limits for passenger vehicles M1 [22]

\begin{tabular}{|c|c|c|c|c|c|c|}
\hline \multirow{2}{*}{ Stage } & \multirow[t]{2}{*}{ Date } & CO & HC & $\mathrm{O}_{x}^{\mathrm{HC}+\mathrm{N}}$ & NO $_{x}$ & $\begin{array}{l}\text { Particulate } \\
\text { matter }\end{array}$ \\
\hline & & \multicolumn{5}{|c|}{$\mathrm{g} / \mathrm{kWh}$} \\
\hline \multicolumn{7}{|c|}{ Clengines } \\
\hline Euro 1 & $07 / 1992$ & 2.72 & & 0.97 & & 0.14 \\
\hline Euro 2 & $01 / 1996$ & 1.0 & & 0.7 & & 0.08 \\
\hline Euro 3 & $01 / 2000$ & 0.64 & & 0.56 & 0.50 & 0.05 \\
\hline Euro 4 & $01 / 2005$ & 0.50 & & 0.30 & 0.25 & 0.025 \\
\hline Euro 5 & $01 / 2011$ & 0.50 & & 0.23 & 0.18 & 0.005 \\
\hline Euro 6 & $09 / 2014$ & 0.50 & & 0.17 & 0.08 & 0.005 \\
\hline \multicolumn{7}{|c|}{ Sl engines } \\
\hline Euro 1 & $07 / 1992$ & 2.72 & & 0.97 & & \\
\hline Euro 2 & $01 / 1996$ & 2.2 & & 0.5 & & \\
\hline Euro 3 & $01 / 2000$ & 2.3 & 0.20 & & 0.15 & \\
\hline Euro 4 & $01 / 2005$ & 1.0 & 0.10 & & 0.08 & \\
\hline Euro 5 & $01 / 2011$ & 1.0 & 0.10 & & 0.06 & 0.005 \\
\hline Euro 6 & $09 / 2014$ & 1.0 & 0.10 & & 0.06 & 0.005 \\
\hline
\end{tabular}

Emission limits for $\mathrm{Cl}$ engines in heavy goods vehic les is shown in Table 2.

Table 2 Emission limits for CI engines in heavy goods vehicles [22]

\begin{tabular}{|c|c|c|c|c|c|c|c|}
\hline \multirow[t]{2}{*}{ Stage } & \multirow{2}{*}{\multicolumn{2}{|c|}{ Date }} & $\mathbf{C O}$ & HC & $\mathrm{NO}_{x}$ & $\begin{array}{l}\text { Particulate } \\
\text { matter }\end{array}$ & \multirow{2}{*}{$\begin{array}{r}\begin{array}{r}\text { smoke } \\
\text { opacity }\end{array} \\
\mathrm{m}^{-1} \\
\end{array}$} \\
\hline & & & \multicolumn{4}{|c|}{$\mathrm{g} / \mathrm{kWh}$} & \\
\hline \multirow{2}{*}{ Euro I } & \multirow{2}{*}{$2^{199}$} & $\mathrm{~kW}^{<85}$ & 4.5 & 1.1 & 8.0 & 0.612 & \\
\hline & & $\mathrm{kW}^{>85}$ & 4.5 & 1.1 & 8.0 & 0.36 & \\
\hline Euro II & \multicolumn{2}{|c|}{$1 / 1996$} & 4.0 & 1.1 & 7.0 & 0.25 & \\
\hline Euro III & \multicolumn{2}{|c|}{$10 / 2000$} & 2.1 & 0.66 & 5.0 & 0.10 & 0.8 \\
\hline Euro IV & \multicolumn{2}{|c|}{$10 / 2005$} & 1.5 & 0.46 & 3.5 & 0.02 & 0.5 \\
\hline Euro $\mathrm{V}$ & \multicolumn{2}{|c|}{$10 / 2008$} & 1.5 & 0.46 & 2.0 & 0.02 & 0.5 \\
\hline EEV & & & 1.5 & 0.25 & 2.0 & 0.02 & 0.15 \\
\hline Euro VI & \multicolumn{2}{|c|}{$01 / 2016$} & 1.5 & 0.13 & 0.4 & 0.01 & \\
\hline
\end{tabular}

These are the limits specified for gases discharged from the exhaust system of the engine. For comparison purposes we can use the emission data published by the electricity producer and calc ulate their amount as per produced $\mathrm{kWh}$ of electric energy at the power plant teminals. This information is specified in Table 3

Table 3 Emissions of power plants in Slovakia [23]

\begin{tabular}{|l|l|l|l|l|l|l|c|}
\hline \multicolumn{10}{|c|}{ Year } \\
\hline & 2011 & 2012 & 2013 & 2014 & 2015 & 2016 & 2017 \\
\hline
\end{tabular}




\begin{tabular}{|c|c|c|c|c|c|c|c|c|}
\hline \multicolumn{2}{|l|}{$\mathrm{SO}_{2}[\mathrm{t}]$} & $\begin{array}{r}40 \\
184\end{array}$ & 33980 & 31381 & 25152 & 47265 & 6393 & 7248 \\
\hline \multirow{2}{*}{$\begin{array}{c}\mathrm{SO} 2 \\
{[\mathrm{~g} / \mathrm{kWh}]}\end{array}$} & $\begin{array}{l}\text { them } \\
\text { al }\end{array}$ & $5^{15.2}$ & 13.18 & 13.73 & 11.35 & 22.19 & 3.10 & 3.30 \\
\hline & $\begin{array}{c}\text { SR in } \\
\text { total }\end{array}$ & 1.79 & 1.53 & 1.37 & 1.14 & 2.14 & 0.34 & 0.37 \\
\hline \multicolumn{2}{|c|}{$\mathrm{CO}_{2}[\mathrm{t}]$} & & & $00^{26750}$ & $00^{24530}$ & $00^{25360}$ & $00^{23050}$ & $0^{240900}$ \\
\hline \multirow{2}{*}{$\begin{array}{c}\mathrm{CO}_{2} \\
{[\mathrm{~g} / \mathrm{kWh}]}\end{array}$} & $\begin{array}{l}\text { them } \\
\text { al }\end{array}$ & & & 1170.7 & 1106.9 & 1190.6 & $5^{1119 .}$ & 1096.0 \\
\hline & $\begin{array}{c}\text { SR in } \\
\text { total }\end{array}$ & & & 117.1 & 111.0 & 114.7 & 121.4 & 123.9 \\
\hline \multicolumn{2}{|l|}{ CO [t] } & 838 & 777 & 721 & 707 & 700 & 1144 & 974 \\
\hline & $\begin{array}{l}\text { them } \\
\text { al }\end{array}$ & $80^{0.31}$ & 0.3014 & 0.3155 & 0.3190 & 0.3286 & $6^{0.555}$ & 0.4431 \\
\hline & $\begin{array}{c}\text { SR in } \\
\text { total }\end{array}$ & $7^{0.03}$ & 0.035 & 0.032 & 0.032 & 0.032 & 0.060 & 0.050 \\
\hline \multicolumn{2}{|c|}{$\mathrm{NO}_{x}[\mathrm{t}]$} & $6^{4,85}$ & 4,145 & 3,449 & 3,373 & 3,885 & 1,887 & 1,824 \\
\hline \multirow{2}{*}{$\begin{array}{c}\mathrm{NO}_{\mathrm{x}} \\
{[\mathrm{g} / \mathrm{kWh}]}\end{array}$} & al therm & 1.84 & 1.61 & 1.51 & 1.52 & 1.82 & 0.92 & 0.83 \\
\hline & $\begin{array}{c}\text { SR in } \\
\text { total }\end{array}$ & $6^{0.21}$ & 0.186 & 0.151 & 0.153 & 0.176 & 0.099 & 0.094 \\
\hline \multicolumn{2}{|l|}{$\mathbf{Z}$ [t] } & 541 & 340 & 313 & 313 & 533 & 169 & 102 \\
\hline \multirow{2}{*}{$\underset{[\mathrm{g} / \mathrm{kWh}]}{\mathrm{Z}}$} & $\begin{array}{l}\text { them } \\
\text { al }\end{array}$ & $5^{0.20}$ & 0.132 & 0.137 & 0.141 & 0.250 & 0.082 & 0.046 \\
\hline & $\begin{array}{r}\text { SR in } \\
\text { total }\end{array}$ & $41^{0.02}$ & 0.0153 & 0.0137 & 0.0142 & 0.0241 & $9^{0.008}$ & 0.00525 \\
\hline \multirow{5}{*}{ 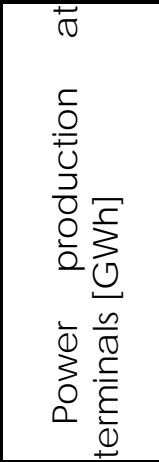 } & nuclear & $74^{14,5}$ & 15,495 & 15,720 & 15,499 & 15,146 & $4^{14,77}$ & 15,081 \\
\hline & themal & $5^{2,63}$ & 2,578 & 2,285 & 2,216 & 2,130 & 2,059 & 2,198 \\
\hline & $\begin{array}{l}\text { Hydroelect } \\
\text { ric }\end{array}$ & $0^{2,88}$ & 1,711 & 1,896 & 2,006 & 1,981 & 2,146 & 2,163 \\
\hline & Gabčíkovo & $5^{2,37}$ & 2,459 & 2,619 & 2,043 & 448 & na & na \\
\hline & In total & $63^{22,4}$ & 22,245 & 22,843 & 22,105 & 22,105 & $1^{18,98}$ & 19,444 \\
\hline \multicolumn{2}{|c|}{$\begin{array}{l}\% \text { share of thermal } \\
\text { plants on the total } \\
\text { powerproduction }\end{array}$} & $3^{11.7}$ & 11.59 & 10.00 & 10.02 & 9.64 & 10.85 & 11.30 \\
\hline
\end{tabular}

\section{SIMULATION}

If we compare Table 1, 2 and 3 we conclude that the legislation did not take into consideration production of $\mathrm{SO}_{2}$ by motor vehic les [21]. This is due to the fact that $1 \mathrm{~kg}$ of diesel oil may contain only less than $10 \mathrm{mg}$ of sulphur. This means that if the company Slovnaft Bratisla va produc es 3 million tons of diesel oil a year [20], this may c onta in only 30 tons of sulphur. Even after inc reasing the weight after combination with oxygen it is definitely less than what is produced by power plants. Other components are compared in Table 5 . For the category $\mathrm{M} 1$ vehicles we considered the energy intensity of a single urban cycle $0.48 \mathrm{kWh}$ at the travelled distance of $1.013 \mathrm{~km}$ [19]. The $\mathrm{CO}_{2}$ production in Sl engines was substituted by the value specified in the vehicle fuel consumption and adjusted it with regard to the energy intensity of the urban cycle. Slovakia is one of the countries 
where the share of themal power plants reaches deep under the EU average. Table 4 shows the overview of the share of fuel type in the EU powerproduction in 2015.

Table $4 \%$ share of the fuel type in the EU power production in 2015 [23]

\begin{tabular}{|c|c|c|c|c|c|c|}
\hline fuel type & Coal & Oil & $\begin{array}{c}\text { Natur } \\
\text { al gas }\end{array}$ & $\begin{array}{c}\text { Nucle } \\
\text { ar } \\
\text { energy }\end{array}$ & $\begin{array}{c}\text { Renewa } \\
\text { ble sources }\end{array}$ & Other \\
\hline $\begin{array}{c}\text { share } \\
\text { [\%] }\end{array}$ & 18.9 & 9.0 & 14.0 & 28.9 & 26.7 & 2.5 \\
\hline $\begin{array}{c}\text { in total for thermal } \\
\text { plants [\%] }\end{array}$ & 41.9 & 28.9 & 26.7 & 2.5 \\
\hline
\end{tabular}

\section{RESULTS}

We added one line in Table 5 which converts the amount of emissions to the share of electric energy in the whole EU. If we want to be thorough we have to state that even the production of electric energy by nuclear power plants or by photovoltaic cells is not without emissions. According to [7] we can consider production of $\mathrm{CO}_{2}$ by photovoltaic panel at the level of $45 \mathrm{~g} / \mathrm{kWh}$ and by nuclear power plant at $20-40 \mathrm{~g} / \mathrm{kWh}$.

Table 5 Comparison of the emissions produced by power plants and the latest applicable limits for vehicles

\begin{tabular}{|l|l|l|l|l|}
\hline & \multicolumn{2}{|l|}{$\mathbf{~} \mathbf{k W h}$} & \multicolumn{2}{l|}{} \\
\hline Emission & $\mathrm{CO}$ & $\mathrm{CO}_{2}$ & $\mathrm{NO} \times$ & $\begin{array}{c}\text { Partic ulate } \\
\text { matter }\end{array}$ \\
\hline Heavy goods vehic les & 1.5 & - & 0.4 & 0.01 \\
\hline Sl engines for M1 vehic les & 0.989 & 253 & 0.06 & 0.06 \\
\hline Total production of power in SR & 0.050 & 123.9 & 0.094 & 0.00525 \\
\hline Themal plants in SR & 0.443 & 1096.0 & 0.83 & 0.046 \\
\hline $\begin{array}{c}\text { Emissions in EU for the share of } \\
\text { themal plants 41.9\% }\end{array}$ & 0.186 & 459.2 & 0.348 & 0.019 \\
\hline
\end{tabular}

It would be suitable to offer a nother perspective of the issue. Emissions that we were comparing were emissions in exhaust gases of cars, but we compared them with emissions directly generated in the electric ity production. And this has to be somehow transported to the electric cars. Electric cars use direct current. In this conversion we can consider the efficiency of $\eta_{\text {rectification }}=90 \%$. Produced electric energy must be several times transformed and there are also losses in the distribution. The efficiency of this process at $\eta$ transfer $=98 \%$. The accumulator does not emit the total stored energy either. Effic iency of this exchange varies with regard to the type of accumulator. Table 6 shows an overview of the efficiency of accumulators [24].

Table 6 Accumulator efficiency [8]

\begin{tabular}{|l|l|}
\hline Accumulator & Charge/discharge efficiency [\%] \\
\hline $\mathrm{Li}$-ion & $80-90$ \\
\hline $\mathrm{Pb}$ & $50-92$ \\
\hline $\mathrm{NiMH}$ & 66 \\
\hline
\end{tabular}

Electric cars are equipped with Li-ion accumulators so we can estimate their efficiency at $\eta_{\text {accumulator }}=85 \%$ [7]. While the electric energy gets into the electric motor, part of the produced electric energy disappears (1).

$$
\begin{gathered}
\eta_{t}=\eta_{\text {transfer }} \cdot \eta_{\text {rectification }} \cdot \eta_{\text {accumulator }} \\
\eta_{t}=0,98.0,9.0,85=0,75
\end{gathered}
$$




\section{Logistic $s \&$ Susta ina ble Transp ort \\ Vol. 10, No. 1, J une 2019, 45-54 \\ doi: 10.2478/jlst-2019-0004}

Then we can rewrite Table 5 into Table 7 which considers also losses of the transferred energy.

Table 7 Comparison of the emissions produced by power plants and the latest applicable limits for vehicles

\begin{tabular}{|c|c|c|c|c|}
\hline & \multicolumn{4}{|c|}{ g/kWh } \\
\hline Emission & $\mathrm{CO}$ & $\mathrm{CO}_{2}$ & $\mathrm{NO} \times$ & $\begin{array}{l}\text { Partic ulate } \\
\text { matter }\end{array}$ \\
\hline Heavy goods vehic les & 1.5 & - & 0.4 & 0.01 \\
\hline Sl engines for M 1 vehicles & 0.989 & 253 & 0.06 & 0.06 \\
\hline $\begin{array}{l}\text { Total production of electric } \\
\text { energy in SR }\end{array}$ & 0.067 & 165.2 & 0.125 & 0.007 \\
\hline Thermal plants in SR & 0.591 & 1461.3 & 1.107 & 0.061 \\
\hline $\begin{array}{l}\text { Emissions in EU for the share of } \\
\text { themal plants } 41.9 \%\end{array}$ & 0.248 & 612.3 & 0.464 & 0.025 \\
\hline
\end{tabular}

For the sake of better transparency and possibility to make a comparison, the values from Table 1 -5 are also shown in the form of graphs, Fig. $1-5$.

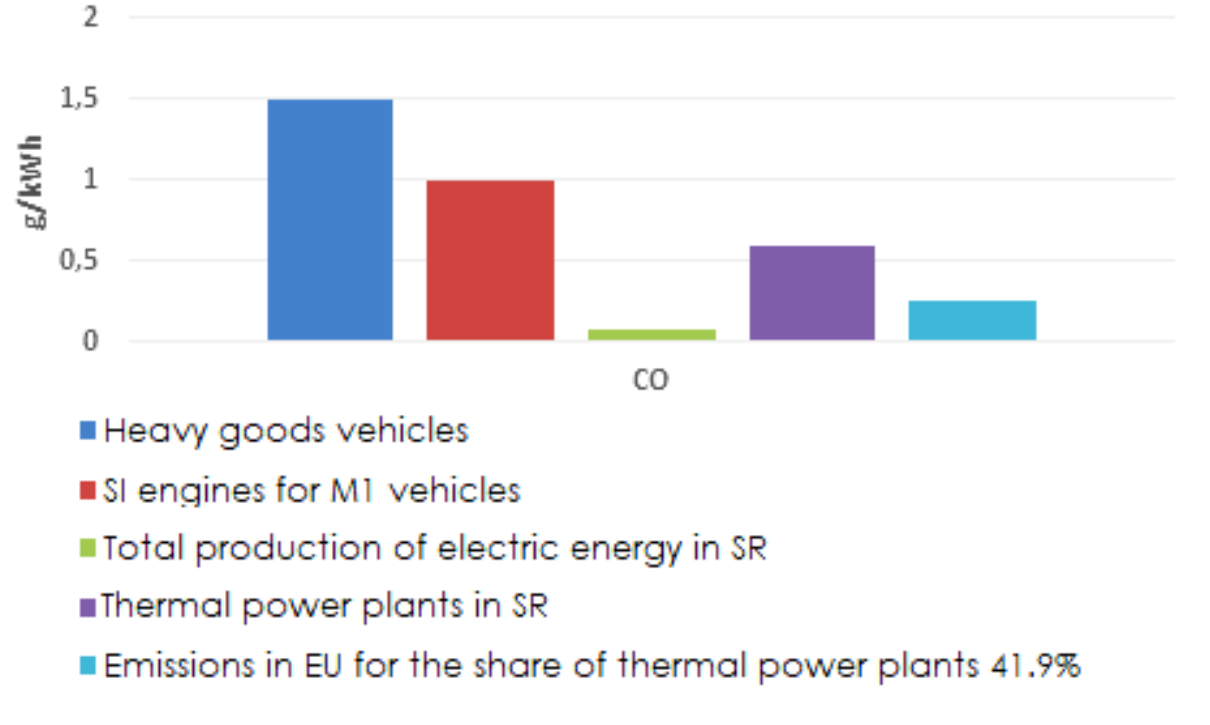

Figure 1 Production of CO per $\mathrm{g} / \mathrm{kwh}$

As follows from the Fig. 1, the heavy goods vehicles and $\mathrm{Sl}$ engines for $\mathrm{M} 1$ vehicles have the biggest share in production of $\mathrm{CO}$ emissions after their recalculation into $\mathrm{G} / \mathrm{kwh}$. It is necessary, for the sake of objectiveness, to note that just those vehicles with a intemal combustion engine are driving most across populated regions, and the population is, thus, exposed to adverse effects of CO on their health [29]. 


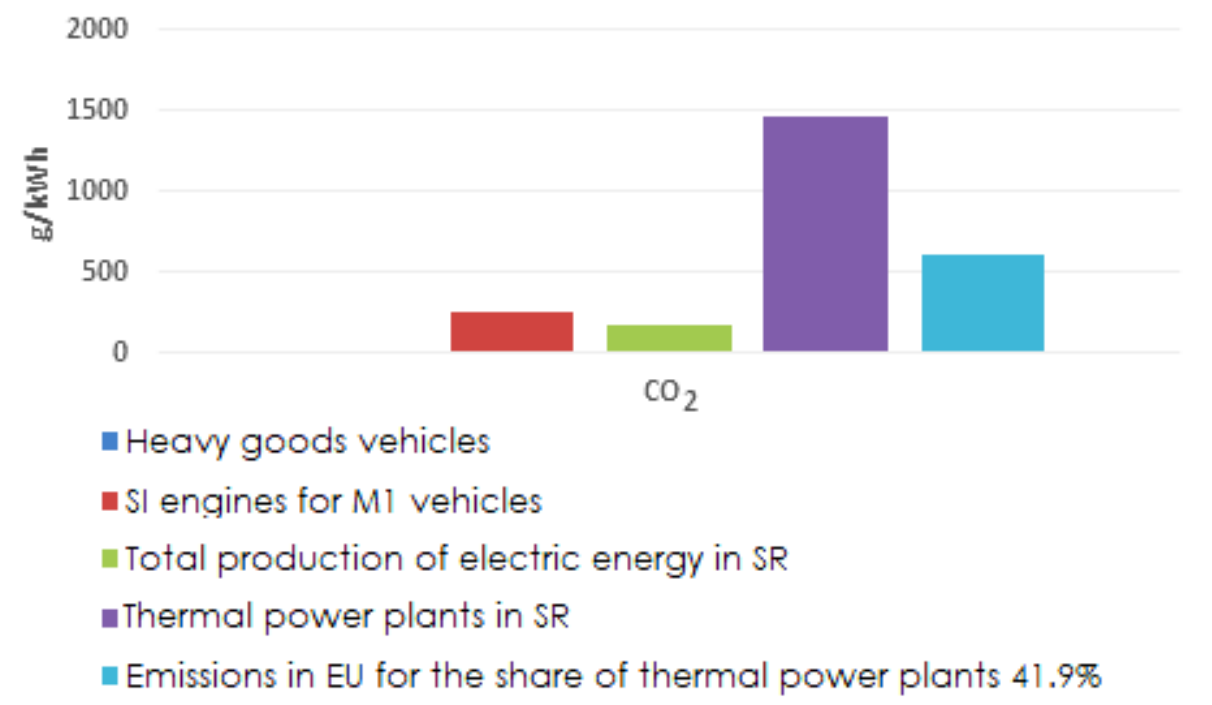

Figure 2 Production of $\mathrm{CO}_{2}$ per $\mathrm{g} / \mathrm{kwh}$

Conceming the production of $\mathrm{CO}_{2}$ grams per $1 \mathrm{KWH}$, the themal plants definitely got the worst results. Their share on overall production of elec tric energy within the Member states of the European Union also was reflected in $\mathrm{CO}_{2}$ emissions evaluation from all the European plants. Since Slovak plants are underrepresented, the production of $\mathrm{CO}_{2}$ in $\mathrm{g} / \mathrm{kwh}$ is lowerthan vehic les of category MI.

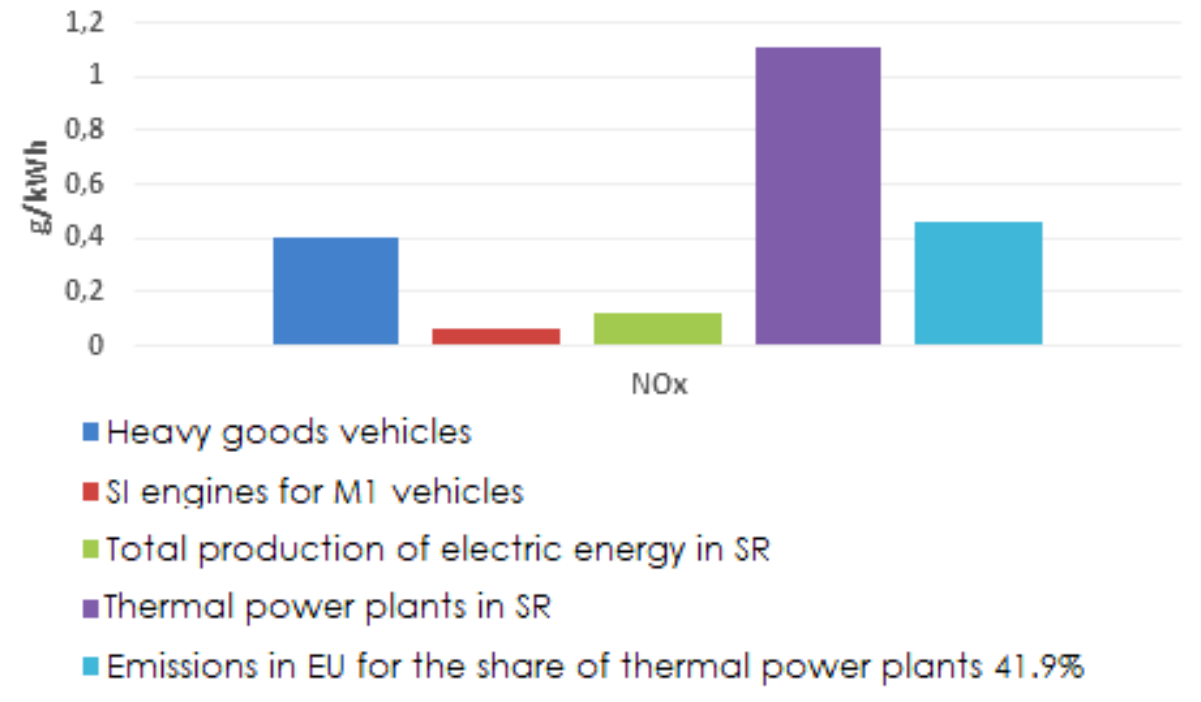

Figure 3 Production of NOx per $\mathrm{g} / \mathrm{kwh}$

Conceming $\mathrm{NO}_{x}$ production, these pollutants are signific antly produced merely by the electric energy plant. $\mathrm{NO}_{x}$ are formed in a combustion space of the engine under the conditions of high temperature, high pressures as well as high excess of oxygen [26]. These parameters are reached by $\mathrm{Cl}$ engines in heavy goods vehic les [27]. Sl engines of vehicles category $\mathrm{M} 1 \mathrm{crea}$ te such conditions exc eptiona lly only and, therefore, NOx emissions a re the lowest of all ca tegories compared [26]. 


\section{Logistic $s \&$ Susta ina ble Transp ort \\ Vol. 10, No. 1, J une 2019, 45-54 \\ doi: 10.2478/jlst-2019-0004}

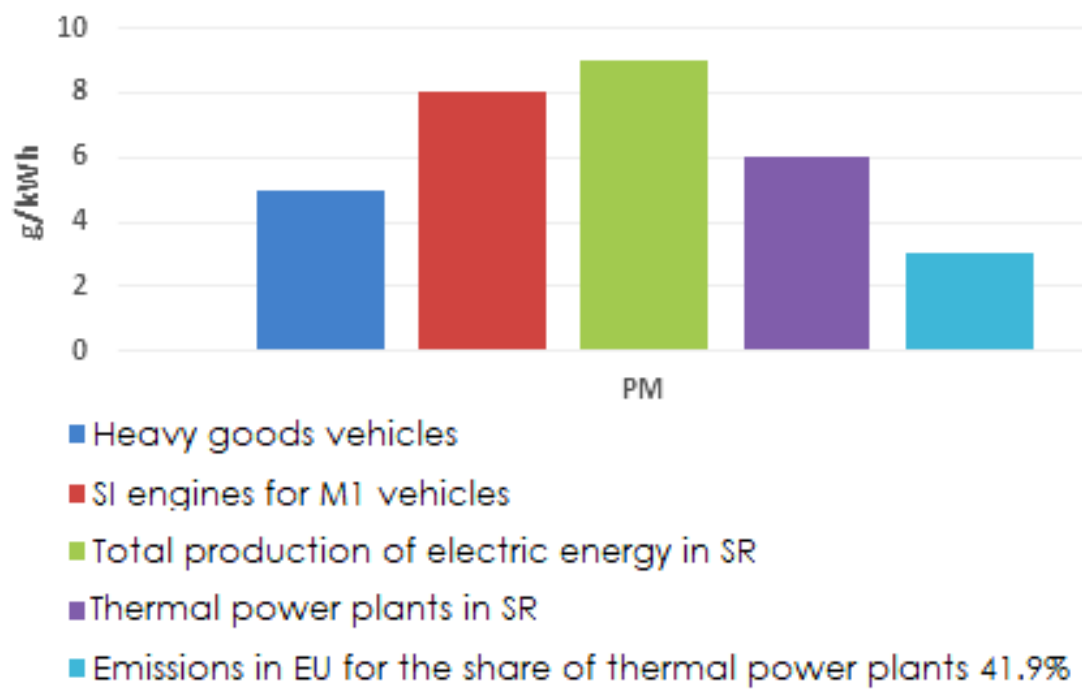

Figure 4 Production of PM per $\mathrm{g} / \mathrm{kwh}$

Relating to a comparison of production of particulates, producing an electric power in Slovakia has the most negative effect on the production of emissions.

\section{CONCLUSION}

The results of calculations from this article made possible to compare the pollutants produced by particular types of vehic les and plants. Based on the calculations in this article, two assumptions can be made. The first assumption is that the expansion of electric vehicles in the European Union would reduce carbon monoxide and particulate emissions. The second assumption is that emissions of carbon dioxide and nitrogen oxides have been increased. As also mentioned in the text above, disadvantage of vehicles with a combustion engine is that they produce pollutants in populated regions. However, their hamful effects can be eliminated by creating low-emission zones, by prohibiting heavy goods vehicles to enter densely populated areas and their further partial replacement with electric cars [28]. Electric cars are also producers of hamful emissions, even indirectly. They use the energy which can lead to the production of emissions, although not directly in populated regions. To speak about electric traction as emission-less is rather debatable. Naturally, there are countries which produce their electric power from renewable sources, such as Norway, Ic eland and some other, and for which the shift to electric traction will really be beneficial, but the global shift of the entire EU is, in our opinion, not an optimum solution.

\section{ACKNOWLEDGMENT}

This work was supported in part by the Grant VEGA no. 1/0436/18 - Extemalities in road transport, an origin, causes and economic impacts of transport measures

\section{REFERENCES}

[1] Sorokin, LV., Mondello, G., (2018) Entering the New +2 degrees C Global Waming Age and a Threat of World Ocean Expansion for Sustainable Economic Development. Climate change, Extreme events and disaster reduction: Towards susta inable development goals. DOI: 10.1007/978-3-319-56469-2_13

[2] Velumani, A., Saravanan, K., Nedunchezhian, N., \& Ganesan, K. (2013). Model Development to Predict Global Waming Potential Due to the Transportation of Municipal Solid Waste Through an Experimental Study. Energy Sources, Part A: Recovery, Utilization, And Environmental Effects, 36(1), 45-53. doi: 10.1080/15567036.2010.536818Chen, W. K. (1993). Linear Networks and Systems, Belmont, CA: Wadsworth, pp. 123-135.

[3] Bertoa, R., \& Astorga, C. (2018). Impact of cold temperature on Euro 6 passenger car emissions. Environmental Pollution, 234, 318-329. doi: 10.1016/j.envpol.2017.10.096

[4] Birkavs, A., Birzietis, G. and Dukulis, I. M. (2012). "Evaluation of Emissions Operating Diesel Engine With Rapeseed Oil and Fossil Diesel Fusel Blends," IEEE Trans. on Neural Networks, vol. 4, pp. 570-578

[5] Synák, F., Rievaj, V., “2017) „The Impact of Driving Resistances of a Vehicle on Global Pollution“, In: 17 th Intemational Scientific Conference Globalization and Its Socio-Economic Consequences, pp: 2602 - 2609, ISBN 978-80-8154-212-1

[6] Villamor, JDV., Rey-Baltar, DZ (2015). "The impact of melting icebergs on sea level," Revista Eureka Sobre Ensenanza y Divulagacion de las Ciencias, vol. 12, pp. 178-185, DOI: 10.25267/Rev_Eureka_ensen_divulg_cienc.2015.v12.i1.12 


\section{Logistic s \& Susta ina ble Transport \\ Vol. 10, No. 1, J une 2019, 45-54 \\ doi: 10.2478/jlst-2019-0004}

[7] Skrucany, T., Harantova, V., Kendra, M., Barta, D. (2017). Reducing Energy Consumption by Passenger Car with Using of Non-Electrical Hybrid Drive Technology“ Advances In Science And Technology Research J oumal, vol:11(1), pp:166-172. Doi: $10.12913 / 22998624 / 66505$

[8] Rievaj, V, Synak, F., (2017). “Does Electric Car Produce Emissions?” Scientific J oumal Of Silesian University Of Technology. Series Transport, vol. 94, pp. 187-197, Doi: 10.20858/sjsutst.2017.94.17

[9] Sarkan, B., Caban, J., Marczuk, A., Vrabel, J., Gnap, J., (2017) „Composition of exhaust gases of spark ignition engines under conditions of periodic inspection of vehicles in Slovakia" Premysl Chemiczny, 2017, vol. 96, pp. 675-680, DOI: 10.15199/62.2017.3.36

[10] Sarkan, B., Caban, J., Marczuk, A., Vrabel, J., Gnap, J., (2017) „Composition of exhaust gases of spark ignition engines under conditions of periodic inspection of vehicles in Slovakia" Premysl Chemiczny, vol. 96, pp. 675-680, DOI: $10.15199 / 62.2017 .3 .36$

[11] Liu, H., Ma, G., Ma, N., Zheng, Z, Huang, H., \& Yao, M. (2018). “Effects of charge concentration and reactivity stratification on combustion and emission characteristics of a PFI-DI dual injection engine under low load condition" Fuel, vol. 231, pp. 26-36. Doi: 10.1016/j.fuel.2018.05.027

[12] Hess, DR., (2017), "Inhaled Carbon Monoxide: From Toxin to Therapy" Respiratory care, vol. 62, pp. 1333-1342, DOI: $10.4187 /$ respcare.05781

[13] Sejkorová, M., Šarkan, B., Vemer, J . (2017). Efficiency Assessment of Fuel Bome Catalyst. MATEC Web Of Conferences, vol. 134, České Budejovice, Czech republic, Doi: 10., 1051/matecconf/201713400051

[14] Sani, S., Kaisan, M., Kulla, D., Obi, A., Jibrin, A., \& Ashok, B. (2018). „Determination of physico chemical properties of biodiesel from Citrullus lanatus seeds oil and diesel blends“ Industrial Crops And Products, vol. 122, pp. 702-708. Doi: 10.1016/j.ind crop.2018.06.002

[15] L, Z, Lu, G., Cui, X., Sun, X., Li, S., \& Qian, Y. et al. (2018). „Effects of the variation in diesel fuel components on the particulate matter and unregulated gaseous emissions from a common rail diesel engine“ Fuel, vol. 232, pp. 279-289. Doi: 10.1016/j.fuel.2018.05.170

[16] Shim, E., Park, H., \& Bae, C. (2018). Intake a ir strategy for low HC and CO emissions in dual-fuel (CNG-diesel) premixed charge compression ignition engine. Applied Energy, vol. 225, pp. 1068-1077. Doi: 10.1016/j.apenergy.2018.05.060

[17] Boriboonsomsin, K., Durbin, T., Scora, G., J ohnson, K., Sandez, D., \& Vu, A. et al. (2018). Real-world exhaust temperature profiles of on-road heavy-duty diesel vehicles equipped with selective catalytic reduction. Science Of The Total Environment, vol. 634, pp. 909-921. Doi: 10.1016/j.scitotenv.2018.03.362

[18] Maricq, M., Bilby, D. (2018). The impact of voltage and flow on the electrostatic soot sensor and the implications for its use as a diesel particulate filter monitor. Joumal Of Aerosol Science, vol. 124, pp. 41-53. Doi: 10.1016/j.ja erosci.2018.07.002

[19] Shim, B., Park, K., Koo, J. and J in, S.(2014) "Work and speed based engine operation condition a nalysis for new European driving cycle (NEDC)." J oumal of Mechanical Science and Technology, vol. 28(2), pp.755-761

[20] Slovnaft: annual report. (2017) https://slovnaft.sk/images/slovnaft/pdf/o_nas/pre_investorov/financne_spravy/vyrocne_spravy/2017/SLN_Vyrocna_Spra va_2017_SK_Web.pdf, Publisher: Slovnaft à.s.

[21] Ramos, A., Munoz, J., Andres, F., Ammas, O., “NOx emissions from diesel light duty vehicle tested under NEDC and realword driving conditions" Transportation research part D - Transport and environment, 2018, Vol. 63, pp. 37 - 48, DOI: 10.1016/j.trd.2018.04.018

[22] Regulation (EC) No 715/2007 of the European Parliament and of the Council of 20 J une 2007 on type approval of motor vehicles with respect to emissions from light passenger and commercial vehicles (Euro 5 and Euro 6) and on access to vehicle repair and maintenance information Sarkan, B., Skrucany, T., Semanova, S., et al., (2018) "Vehicle coast-down method as a tool for calculating total resistance for the purposes of type-approval fuel consumption" , Scientific J oumal Of Silesian University Of Technology. Series Transport, vol. 98, pp.161-172, Doi: 10.20858/sjsutst.2018.98.15

[23] SEAS: Annual Report. (2018) https://www.seas.sk/data/publishing/441/file/se-2017-annual-report.pdf

[24] Lu, J., Lin, X., Han, T., L, X., Gu, C. and Li, J ., „A novel litchi-like LFePO4 sphere/reduced graphene oxide composite Liion battery cathode with high capacity, good rate-perfomance and low-temperature property" Applied Surface Science, 2018, 459, pp.233-241., DOI: 10.1016/j.apsusc .2018.07.199

[25] Wang, Z, Zhong, S., He, H., Peng, Z and Cai, M., "Fine-scale variations in PM 2.5 and black carbon concentrations and corresponding influential factors at an urban road intersection". Building and Environment, 141, pp.215-225., DOI: 10.1016/j.buildenv.2018.04.042

[26] Kobaya shi, M., Aoyagi, Y., Adachi, T., Murayama, T., Noda, A., Goto, Y., \& Suzuki, H., “Effects of High Boost and High EGR on the Super Clean Diesel Engine : Evaluation using the Transient Test Cycle" The Proceedings Of The Intemational Symposium On Diagnostics And Modeling Of Combustion In Intemal Combustion Engines, 2008., vol. 7(0), pp. 27-34. Doi: $10.1299 /$ jmsesdm.2008.7.27

[27] Boriboonsomsin, K, Durbin, K., Scora, G., J ohnson, K., Sandez, D., Vu, A,m et al., "Real-world exhaust tempera ture profiles of on-road heavy-duty diesel vehicles equipped with selective catalytic reduction" Science of the total environment, 2018, vol., 634, pp.909-921, DOI: 10.1016/j.scitotenv.2018.03.362

[28] Sarkan, B., Stopka, O., Gnap, J. and Caban, J. (2017). Investigation of Exhaust Emissions of Vehicles with the Spark Ignition Engine within Emission Control. Procedia Engineering, 187, pp.775-782.

[29] Skrucany, T., Vojtek, M., Suchter, G., "Fixation of Tarpaulin Sheet of Platform HDV and its Impact to Air Resistance" Transport technic and technology, 2018, vol. 14, ISSN (Online) 2585-8084, DOI: https://doi.org/10.2478/ttt-2018-0002

[30] Nan, J., Wang, Y., Chai, Z and Huang, J. (2012). Modeling of Electric Vehicle Air Conditioning System and Analysis of Energy Consumption. Advanced Materia ls Research, 516-517, pp.1164-1170.

\section{AUTHORS}


A. Rievaj Vladimír is Associate Professor at the Department of Road and Urban Transport at the University of Zlina, Slovak republic. (e-mail: Vla dimir.rievajr@ fpedas.uniza.sk).

B. Gaňa Ján is a PhD student at the Department of Road and Urban Transport at the University of Žlina, Slovak republic. (e-mail: gana @bte.sk).

C. Synák František is a PhD student at the Department of Road and Urban Transport at the University of Žlina, Slovak republic . (e-ma il: fra ntisek.synak@ fpeda s.uniza.sk).

Manuscript received by 25. October. 2018

Published as submitted by the author(s). 